\title{
ENVIRONMENTAL IMPACT ASSESSMENT OF EGYPTIAN PORTS "A COMPARATIVE STUDY BETWEEN ALEXANDRIA AND SOKHNA"
}

\author{
${ }^{1}$ Mohammed Abdel Moneim, ${ }^{2}$ Iman Siam, and ${ }^{3}$ Ashraf A. Zahran \\ ${ }^{1,2}$ Arab Academy for Science, Technology and Maritime Transport, Egypt \\ ${ }^{3}$ Department of Natural Resources and Planning to Development, Environmental Studies and Research \\ https://doi.org/10.35410/IJAEB.2020.5579
}

\begin{abstract}
This study aims to assess the environmental impact of the projects in the port of Alexandria on reaching the global quality level of the environment "14001" as is applied in the port of Sokhna. In addition, the research considered a comparative study of the situation inside the port of Alexandria and Sokhna for evaluation and future recommendations for reaching an integrated environmental plan to increase their competitiveness. It also aims at finding out the extent to which environmental impact assessment standards and benchmarks are applied from 2017 to 2020. The significance of this research is that it will increase the achievement of occupational safety and health requirements for both employees and customers of the port to prevent accidents, injuries and occupational diseases. This will lead to increasing alignment with the requirements of the environmental management systems in accordance with international quality specifications as well as raising the efficiency of the port of Alexandria and Sokhna and developing them to accommodate modern generations of the technological progress. The research also guides decision makers to coordinate permanently and continuously with the port community to enhance performance and provide high quality service. Finally, the study provides an environmental impact assessment system for all port workers, which will have a positive impact on the implementation of activities and tasks in an accurate and healthy manner.
\end{abstract}

Keywords: Environmental Impact Assessment, Alexandria Port, Sokhna Port.

\section{INTRODUCTION}

The awareness for the environment and its protection has risen for decades and has become an issue that concerns everybody. Environmental issues and depletion of its resources concerns not only the industrialized countries, but also all developed and developing countries.

Industrial and technological progress has been associated with environmental pollution, and the manifestations and causes of environmental pollution have multiplied due to excessive consumption of environmental resources and lack of protection for these resources. Human beings and other creatures have become endangered because of air and water pollution. (Abdul Latif, 2016). 
The environmental impact assessment of projects is a new phenomenon where it was introduced in the United States of America and Europe in 1969 (Qasim, 1999). Environmental assessment is a tool for decision-making in environmental planning. It predicts some of the positive and negative effects of environmental activities and tries to minimize negative impacts and maximize positive effects by formulating possible alternatives to maximize the role of the alternatives (Hani, 2009). The environmental impact is defined as natural, chemical, biological, cultural or socio-economic change in the ecosystem as a result of some projects activities (Siam, 2005). The Environmental Impact Assessment is considered a training on what will be implemented before any project or for what will be pledged to ensure that the environment cannot be harmed by any means in the short or long terms. Therefore, it is the process by which the environmental impacts of an activity are predicted and described. The main objective of evaluating the environmental impact of any activity is making environmental considerations a central focus of decisionmaking and assistance in achieving sustainable development for natural resources (Al-Bunbi, 2000).

Environmental impact assessment has several objectives, which are: modifying and improving project designs, ensuring optimal use of resources, improving and enhancing impact social projects, measuring and minimizing the main impacts of the project, informing decision-makers, assessing the situation and finally avoiding any irreversible damage to the environment. There are also many benefits of Environmental Impact Assessment (Abd-Al-Lateef, 2016):

- Planning and designing the environmental project: the accurate design for the project can reduce risks for environment and people and in this way project-related costs related to repairing, losses and compensations can be avoided.

- Ensuring that the projects are subject to environmental standards which decreases the environmental harms

○ Saving capital and rationalizing expenditures: environmental impact assessment assists in avoiding unneeded expenditures

- Reducing the time and cost of certification of the development application: all environmental aspects should be considered before any project certification, so that the decision-maker takes the suitable environmental actions on time.

- Increasing the public acceptance on the project: the projects can be subject to transparent evaluation through the Environmental Impact Assessment process and the public who are concerned with environmental issues can be encourage to participate in such an evaluation.

\section{LITERATURE REVIEW}

Many studies have been presented in the same field but they differ in subject matter and objectives. Thus, the researcher chose systematic methods and procedures which are consistent with the objectives of this study. Saber (2008) aims to clarify the environmental effects of oil pollution inside and near ports specialized in oil export and its derivatives from petrochemicals. The study focused on the port of Al-Brega specialized in the export of oil and the port then attracted many Petrochemical industries, which necessitated the development of the port and the provision of specialized berths and the work of environmental impact studies for all activities to 
reduce environmental negative impacts as well as to identify alternatives available for activities to reduce the water pollution resulted from.

Dounia (2009) carried out an environmental assessment of the current state of the port of Alexandria. This research mainly aims at studying environmental assessment for the port of Alexandria and then work on a comparative evaluation for the current situation of the port. The researcher relied on the descriptive approach in the current port situation. Data collection is based on previous studies and official interviews with port management and authorities and then providing the environmental assessment of the port. The objective of this assessment is to ensure economic sustainable development that meets the urgent needs of the present time for the development of port management in general, especially the port of Alexandria. The final status of the port has been clarified after the recent significant development, which had several consequences in achieving political, economic, social and marine goals taking into account the increase in the volume of trading at the port. The researcher recommends maintaining the level of protecting the environment in the port of Alexandria and supporting future studies and plans in the development of the port in order to achieve the desired results related to environmental assessment.

Badr (2010) focuses on the environmental impacts that can arise from activities related to the construction and operation of the proposed river port in Qena. The study covers the area around the port in terms of population, climate, socio-economic aspects, groundwater, soil characteristics, port capacity and expected daily traffic intensity. The study suggests a plan to treat waste from navigational activities as drilling and constructions negatively affect water and fish stocks. The data collection in the study is based on information about the establishment of river ports and the current status of navigation in the Nile. The study develops a preliminary vision for the design of river ports and their capacity, which the Egyptian Ministry of Transport plans to add to the existing port network.

Chendvong (2011) discusses the development of ports and used the guidelines adopted by the National Authority to apply the evaluation. The researcher chose the port of Ranong in Thailand as a case study because it is a modern port and has sold in the political situation, and the researcher cares marine natural conditions affecting the environmental assessment of the port, such as the change in water currents in terms of altitude and strength, as well as sediment resulted from slitting caused by waves, which causes disruption in the construction of the port and marine accidents and the pollution caused by the oil affects. This is study is considered one of the first researches about the environmental assessment of ports in Thailand that illustrates the relationship between the economy and the environment, as well as the points of weaknesses and strengths of the environmental assessment system if applied to any other port.

Elgohary and Hassan (2012) were interested in the environmental assessment of large and small ports and the related facilities. In their study, they explain the steps of environmental assessment that will be carried out when the construction of four piers in front of four hotels as well as the construction of two piers in front of the ports in the Area of Sharm Sheikh on the Red Sea coast which is about $34 \mathrm{~km}$ from the city of Qusayr. The study focuses on negative environmental impacts and methods of intimidation of the consequences for the environment. It is demonstrates 
the activities related to the region and its impact on the environment, providing alternatives in case of a negative impact on environment during the construction phase.

The environment in Egypt continues to suffer from the negative effects of many activities that did not take the environment into account and has recently emerged a lot of development projects that are still in the light of planning and need environmental assessment to avoid negative effects on the environment and to help in the sustainable development. Egypt's coastal area is of economic and environmental importance but suffers from loads of agricultural and industrial pollutants. This research sheds light on the guidelines to be followed when assessing the environmental impacts of ports, especially Mediterranean ports. The researcher took the port of Damietta as a case study, so the study assesses the existing environmental situation as well as the infrastructure environment, natural water, the chemicals in marine water as well as the birds and the movement of waves and the researcher also touches on noise and its impact on the social and cultural environment. The analysis was done by a matrix during and after the construction period to illustrate the environmental impact on the social situation before and after the construction of the port (El-Gohary, 2017).

In his study, Dawood (2018) assesses the environmental impact of one of the drilling towers in Baghdad province by identifying a number of indicators to show the negative effects. In order to avoid negative effects and enhance positive effects, an environmental impact assessment tool was used, namely the Rapid Impact Assessment Matrix. The research concludes that there are serious adverse environmental impacts at the drilling site -air and soil pollution- and these effects can be mitigated by developing a comprehensive environmental management plan and speeding up the implementation of the necessary treatments to reduce pollutants from its operations. The company does not have a specific strategy to prevent or reduce pollution, in addition to the lack of environmental awareness among the workers at the drilling site, which is due to the lack of training courses related to environmental quality issues.

Through the review of previous studies, it has been found that there is a deficiency in the application of the environmental management quality system and this is what the researcher aims to study despite the existence of projects within the port of Alexandria, which obliges the environmental management of the port on the need to apply the laws and legislation of environmental assessment, which has not been tackled before.

The previous works on the environmental impact assessment has not been done as a giant project covering all the aspects related to the port of Alexandria since that the project is old, before the application of Law number 4 of 1994 and its amendment - Law 9 of 2009 - and Executive Regulation 258, which contains its necessity to be applied.

\section{RESEARCH PROBLEM}

The port of Alexandria suffers from a lack of applying the environmental impact of the air, water and ground surface (Arafat, 2007). In addition, it has an increase in the amount of solid, liquid and gaseous pollutants based on preliminary surveys that were distributed and assembled from the ports of Alexandria and Sokhna as well as field visits to the Marine Environment Department of both the port of Alexandria and Sokhna, resulting in the inability of the port of Alexandria to 
obtain on the 14001 Global Environmental Quality Certificate as opposed to the acquisition of the Port of Sokhna with the ISO Environmental Certificate 14001.

Based on the previously mentioned problem, the researcher sheds light on the harmful effects on the environment resulting from various projects and activities in the port of Alexandria and Sokhna.

\section{RESEARCH COMMUNITY}

The environmental impact on the ports of Alexandria and Sokhna are assessed in this study during the year 2019. The port of Alexandria is the main port of the Republic of Egypt, located on the northern coast of the Arab Republic of Egypt on the Mediterranean Sea, west of the Nile Delta, and is about $225 \mathrm{~km}$ away from Cairo with an area of 900,000 square meters. The port of Sokhna is located near the southern entrance of the Suez Canal on the Red Sea, making this location a strategic advantage for dealing with transit cargo through the world's busiest commercial waterways. The port of Sokhna is located in the heart of a vital trade route between East and West, $120 \mathrm{~km}$ away from Cairo.

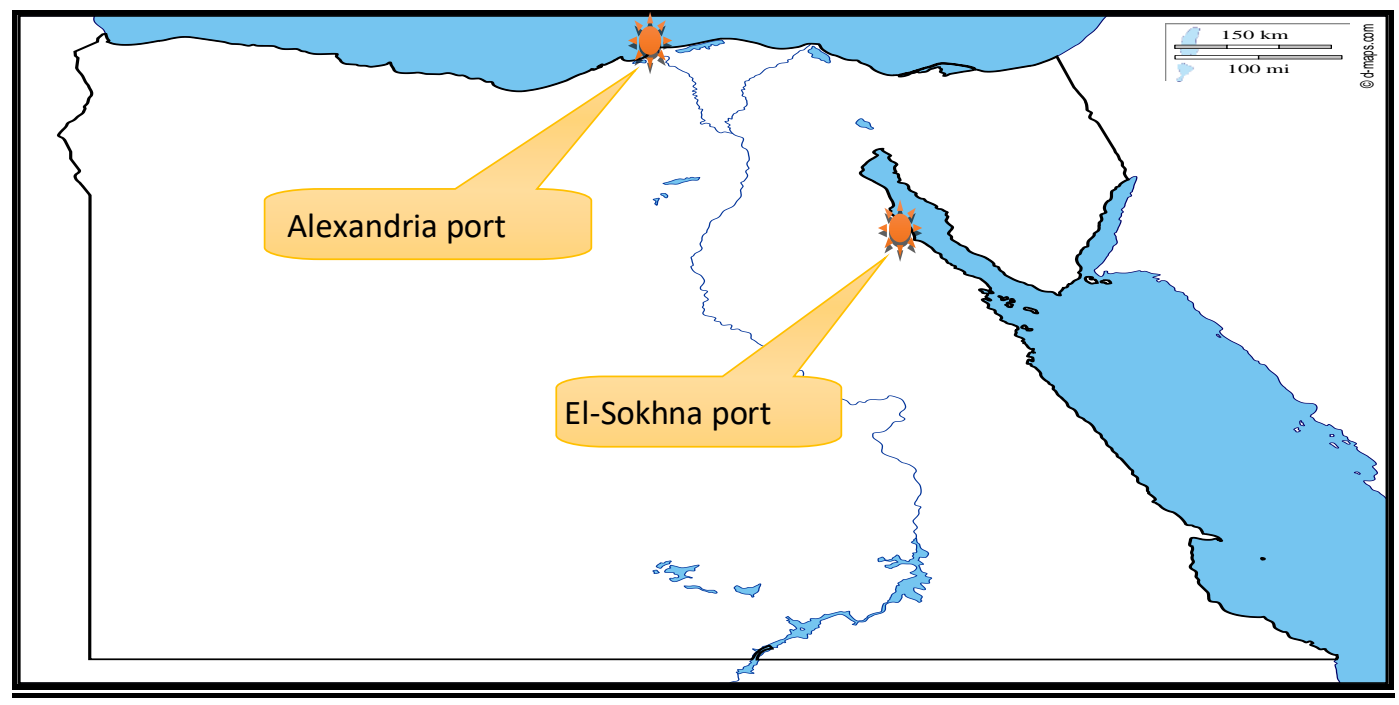

Figure 1. The Egyptian main container terminals.

Source: (D-maps.com, 2020).

\section{RESEARCH METHODOLOGY}

The research design gives comprehensive guidelines for data collection and analysis. The approach used is based on the descriptive analytical approach (Neuman, 2014). The sample that is applied in this research is a stratified sample and not random, dealing only with the ports of Alexandria and Sokhna. The methodology curriculum for any research is classified for only two approaches, deductive and inductive approaches (Saunders et al., 2009). According to the nature of the research, this research follows the deductive approach where it is based on conducting the necessary analysis through the use of laboratory measurements and analyses. 
The research methodology is conducted by taking three steps to achieve the research objectives, as follows: First step: Field visits to Alexandria and Sokhna ports to gather information on various activities and existing projects and the extent of its impact on the surrounding environment as well as meeting the officials to collect the required data.

Step 2: Distribution of a questionnaire on the employees of Alexandria and Sokhna ports to find out how much they understand the environmental impact assessment of the activities in the ports. Step 3: The researcher performs an analysis of air, dust and water for the port of Alexandria and the port of Sokhna using a group of devices specialized in the process of environmental impact assessment and attached to the supplements numbers $(4,3,2)$ by taking samples from air, dust and water for the ports and analyzing them to determine the level of pollutants in each of them, so that the obstacles and difficulties that stand in the way of application of environmental impact assessment and from it to obtain quality certificate in the environment ISO.

\section{RESEARCH VARIABLES}

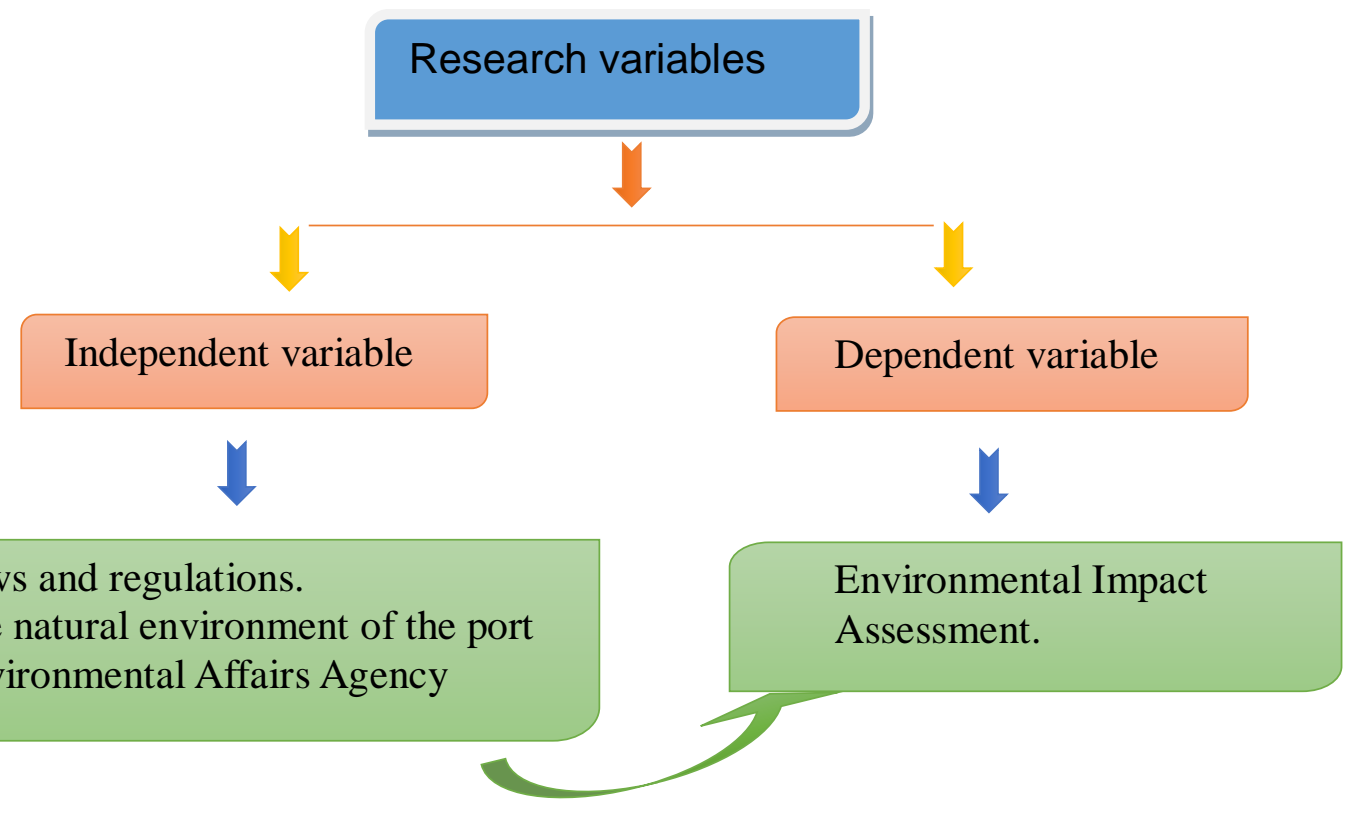

Figure 4. Variable used in thus research.

Source: by the researcher.

\section{Empirical analysis and discussion}

\section{Weather and climate of Sokhna port:}

The location of Sokhna port in Suez is influenced by the climate of the Red Sea, where the governorate of Suez is characterized by dry weather in summer and warm winter. Its maximum 
temperature reaches $34^{\circ} \mathrm{C}$ and the minimum temperature reaches $20^{\circ} \mathrm{C}$ between May and October.

The temperature from November to April is between $23^{\circ} \mathrm{C}$ and $15{ }^{\circ} \mathrm{C}$ with some acute sandstorms coming from some deserts. The figure (2) show wind trend data for different weather conditions in all the four seasons in the study area taken from the nearest monitoring stations (Ismailia and Cairo monitoring station) between the years of 2017 until the beginning of 2020.

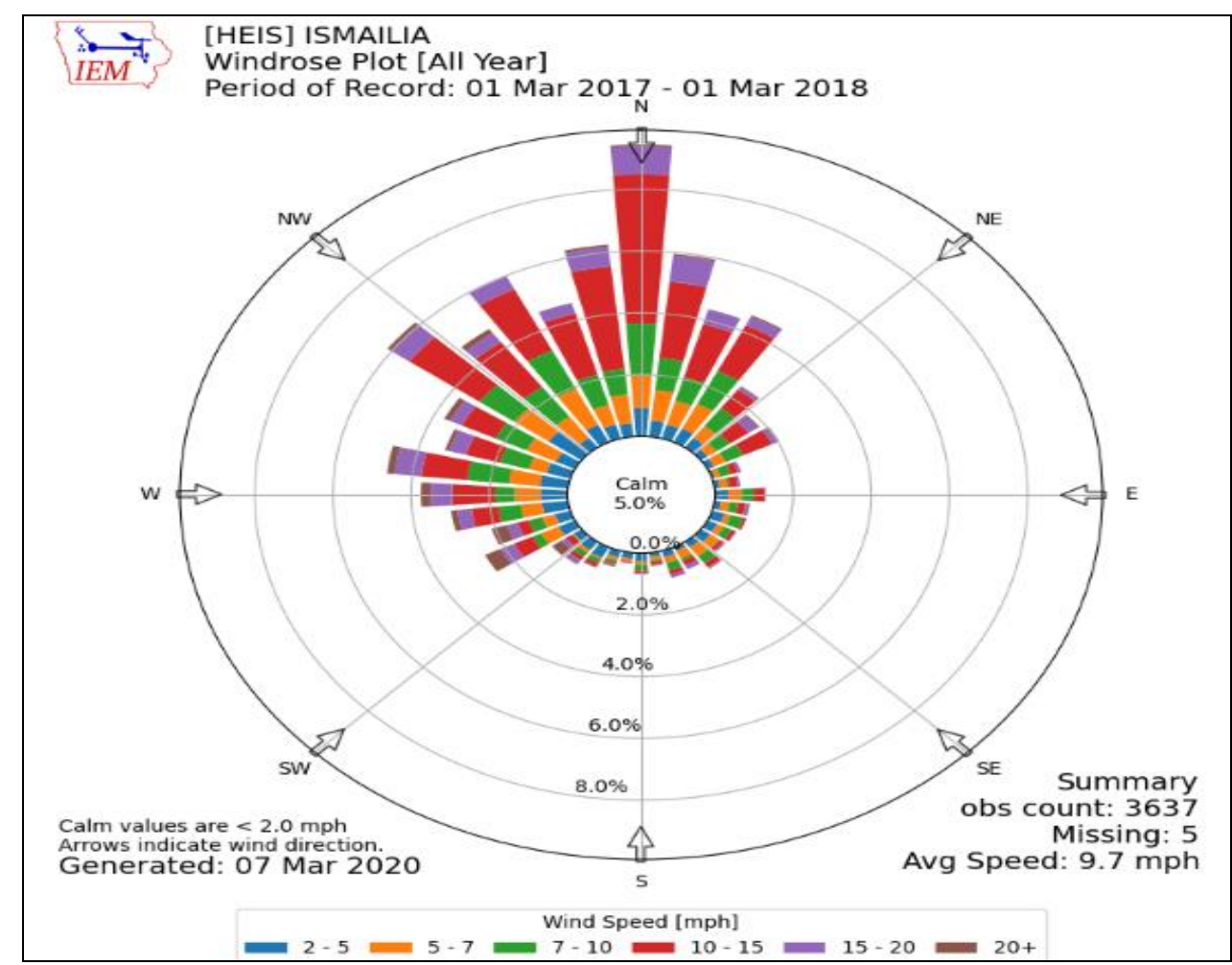

Figure 2. shows the prevailing wind direction during 2017-2018.

Source: Author own elaboration. 
Vol. 5, No. 06; 2020

ISSN: $2456-8643$

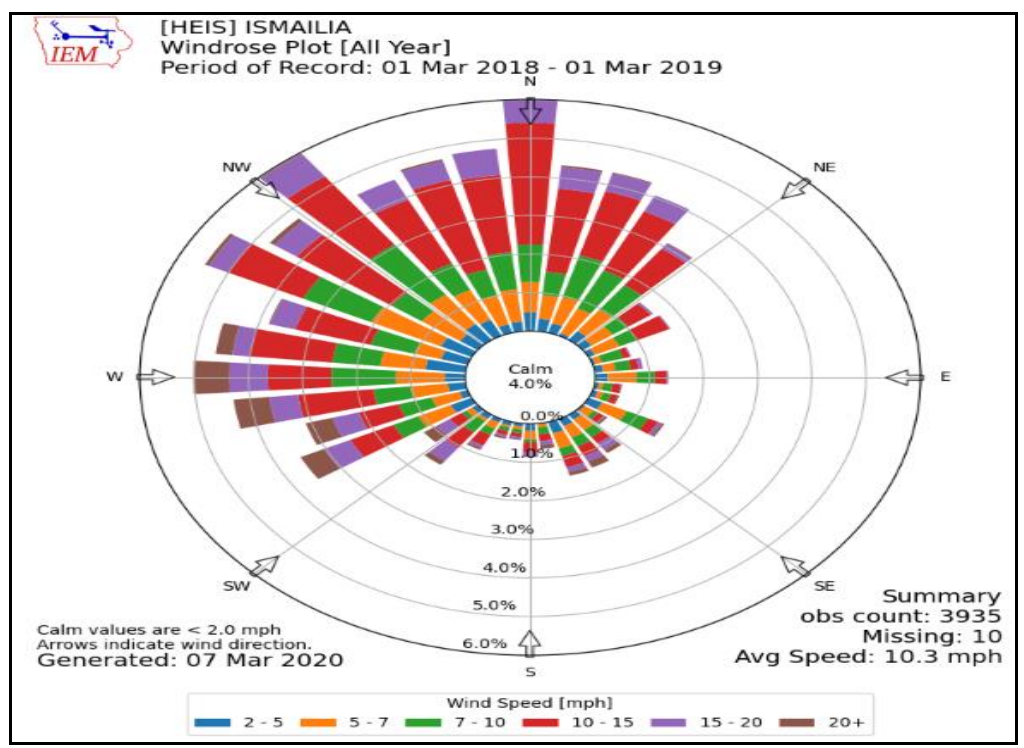

Figure 2. Shows the prevailing wind direction during the year 2018-2019.

Source: Author own elaboration.

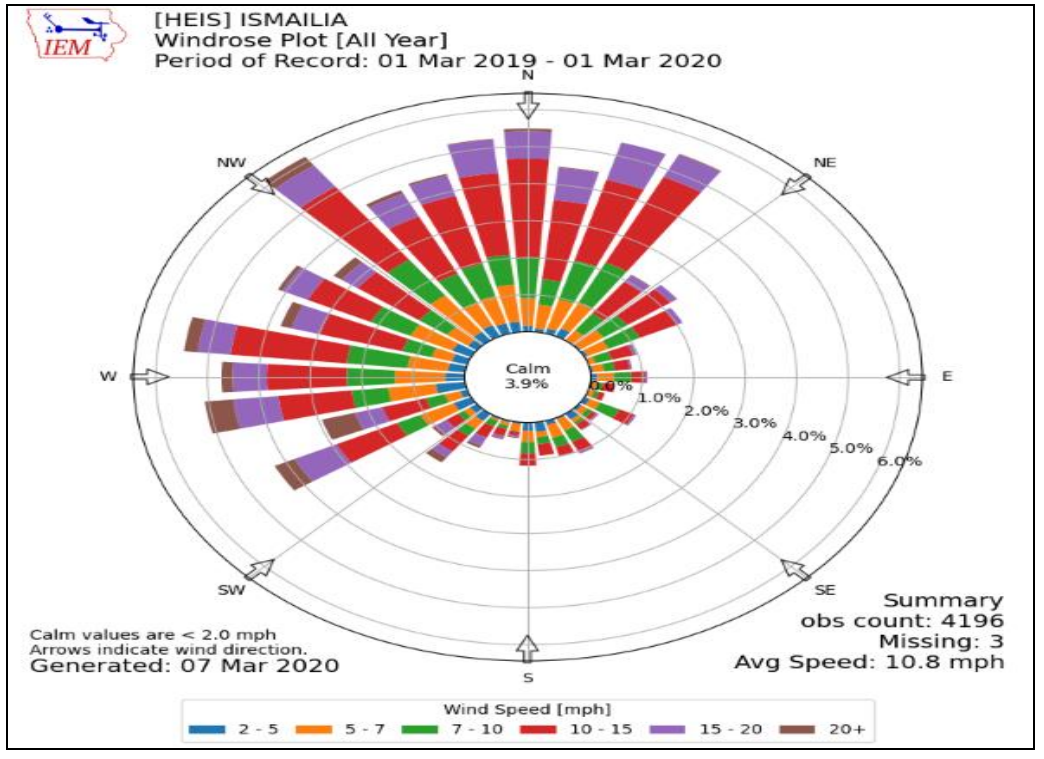

Figure 3. Shows the prevailing wind direction during the year 2019-2020.

Source: Author own elaboration. 
Vol. 5, No. 06; 2020

ISSN: $2456-8643$

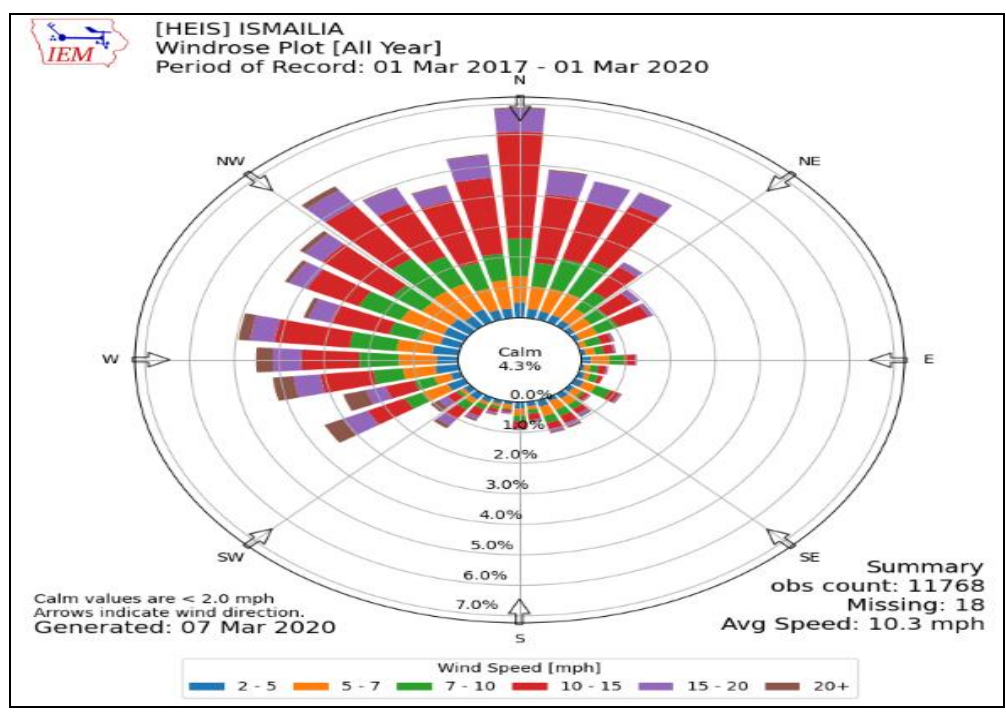

Figure 4. prevailing wind trends in El-Sokhna Port from March 2017 to March 2020.

Source: Author own elaboration.

\section{Sokhna Port Air Quality:}

This procedure has taken place through visiting the site, measuring its coordinates, selecting a number of sites to monitor the various air pollutants around the port, especially the areas above the wind and under the wind to determine the air quality in the region using various equipments (as shown in table 1), which demonstrates pollutants.

Table 1. the different methods and devices used to monitor air quality in the study area.

\begin{tabular}{|c|c|c|}
\hline Pollutants / Elements & The technique used & The used device \\
\hline $\begin{array}{l}\text { TSP } \\
\text { (The suspended overall } \\
\text { dust) }\end{array}$ & \begin{tabular}{|rr} 
dust collection & $\begin{array}{r}\text { (Filtration and } \\
\text { Deposition) }\end{array}$ \\
\end{tabular} & Volume sampler \\
\hline $\begin{array}{l}\text { PM10 } \\
\text { (Thoracic particles) }\end{array}$ & \begin{tabular}{|rr} 
dust collection & (Filtration and \\
& \\
Deposition)
\end{tabular} & Air Matrix \\
\hline Noise & Sound Levels' Sensor & Noise meter \\
\hline $\begin{array}{l}\text { VOC } \\
\text { (Volatile organic gases) }\end{array}$ & $\begin{array}{r}\text { Photo Ionization Detector PID } \\
\text { Gas Chromtograph (GC) }\end{array}$ & $\begin{array}{r}\text { VOC monitor } \\
\text { and sampling canister }\end{array}$ \\
\hline Photos & --- & $\begin{array}{r}\text { Digital Camera and } \begin{array}{r}\text { Satellite } \\
\text { image }\end{array}\end{array}$ \\
\hline Geographical locations & --- & GPS \\
\hline
\end{tabular}




\section{Total Suspended Particulates in Sokhna Port:}

It has been measured in several locations around and inside the port, and northand north-west winds are moving south and southeast the nature of the place is coastal and the nature of Egypt's environment is desert sandy/rocky, therefore, one of the sources of total suspended particulates is from a natural source.

Table (2) Average of the total suspended dust concentrations (micrograms per cubic meter) around Sokhna Port site

\begin{tabular}{|c|c|c|c|c|}
\hline \multirow[t]{2}{*}{ Site No. } & \multicolumn{4}{|c|}{$\begin{array}{l}\text { Air Quality Limit } \\
\mathrm{AQL}=230 \mu \mathrm{g} / \mathrm{m}^{3}\end{array}$} \\
\hline & $\begin{array}{r}\text { Average TSP } \\
2017\end{array}$ & $\begin{array}{r}\text { Average TSP } \\
2018\end{array}$ & $\begin{array}{r}\text { Average TSP } \\
2019\end{array}$ & $\begin{array}{r}\text { Average TSP } \\
2020\end{array}$ \\
\hline West & 51.1 & 55.2 & 95.0 & 46.5 \\
\hline North & 46.1 & \begin{tabular}{|l|l|}
48.3 \\
\end{tabular} & 97.0 & 97.2 \\
\hline East & 50.1 & 52.2 & 107.0 & 108.3 \\
\hline South & 48.6 & 66.2 & 89.0 & 172.7 \\
\hline
\end{tabular}

Source: Author own calculations. 


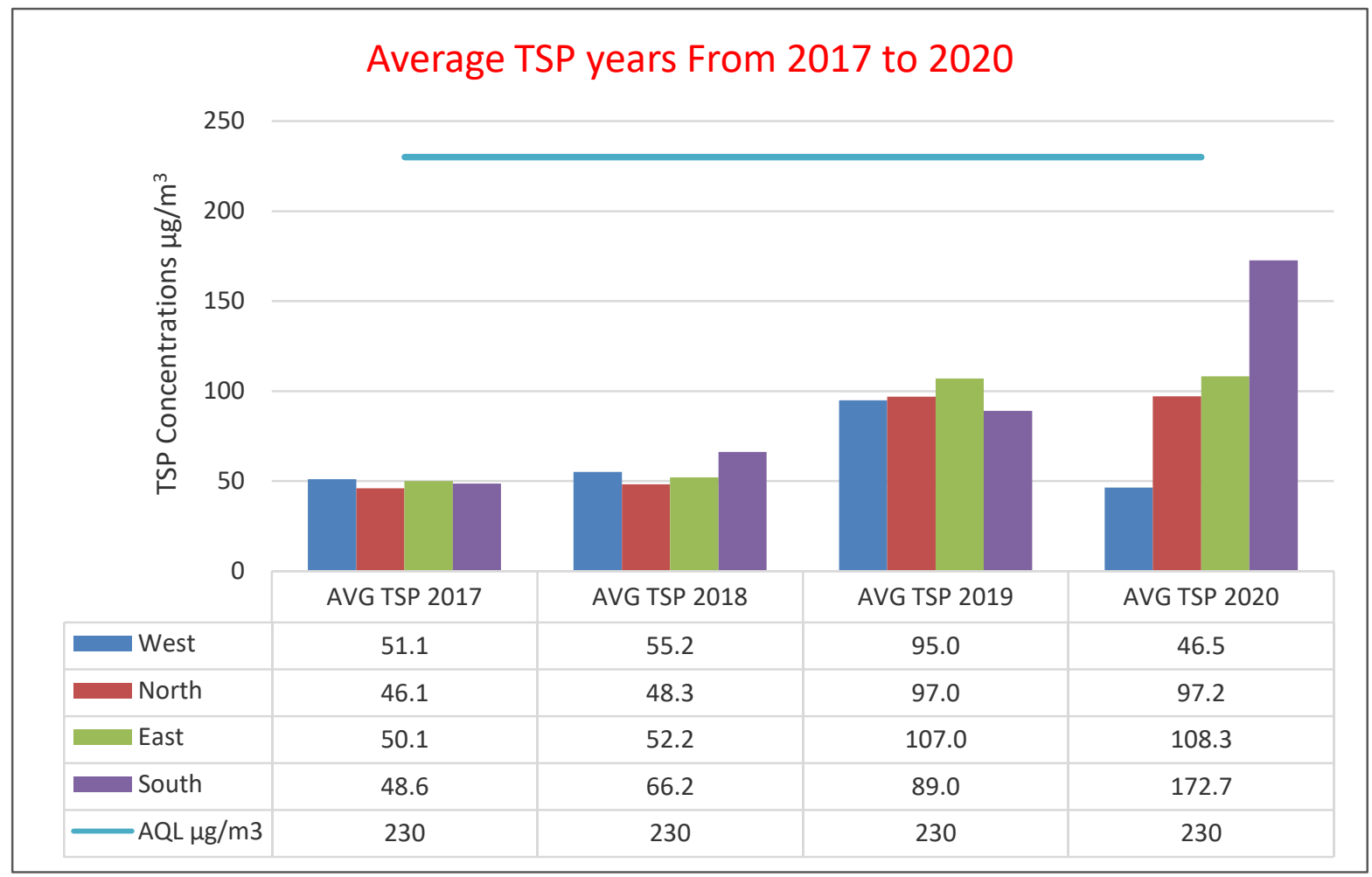

Figure 5. Average of total suspended dust concentrations (micrograms per cubic meter).

Source: Author own calculations.

Measurements of total suspended particulates has been done as shown in table (2) and figure (5) and it turns out that all the points measured did not exceed the permissible limits based on the Egyptian Environment Act in accordance with the latest amendments to the law number 9 of the year 2009.

Table .3 Average of concentrations of thoracic particles (micrograms per cubic meter) around the location of Sokhna Port

\begin{tabular}{|c|c|c|c|c|}
\hline \multirow{2}{*}{ Site No. } & \multicolumn{4}{|c|}{$\begin{array}{l}\text { Air Quality Limit } \\
\text { AQL }=150 \mu \mathrm{g} / \mathrm{m}^{3}\end{array}$} \\
\hline & $\begin{array}{r}\text { Average } \text { PM}_{10} \\
2017\end{array}$ & $\begin{array}{r}\text { Average } \text { PM}_{10} \\
2018\end{array}$ & $\begin{array}{r}\text { Average } \text { PM}_{10} \\
2019\end{array}$ & $\begin{array}{r}\text { Average } \text { PM }_{10} \\
2020\end{array}$ \\
\hline West & 16.4 & 22.2 & 38.4 & 18.1 \\
\hline North & 17.3 & 19.6 & 39.3 & 39.4 \\
\hline
\end{tabular}


Vol. 5, No. 06; 2020

ISSN: $2456-8643$

\begin{tabular}{|r|l|l|l|l|}
\hline East & 21.1 & 21.5 & 43.8 & 43.2 \\
\hline South & 16.3 & 19.1 & 36.1 & 69.2 \\
\hline
\end{tabular}

Source: Author own calculations.

As for the concentrations of thoracic particulates, they are below 10 micrometers, which is considered below the limits allowed by Act 9 for the year 2009 as shown in table (3) and in figure (6). Natural or artificial factors can play a major role in increasing suspended particulates and thoracic particulates.

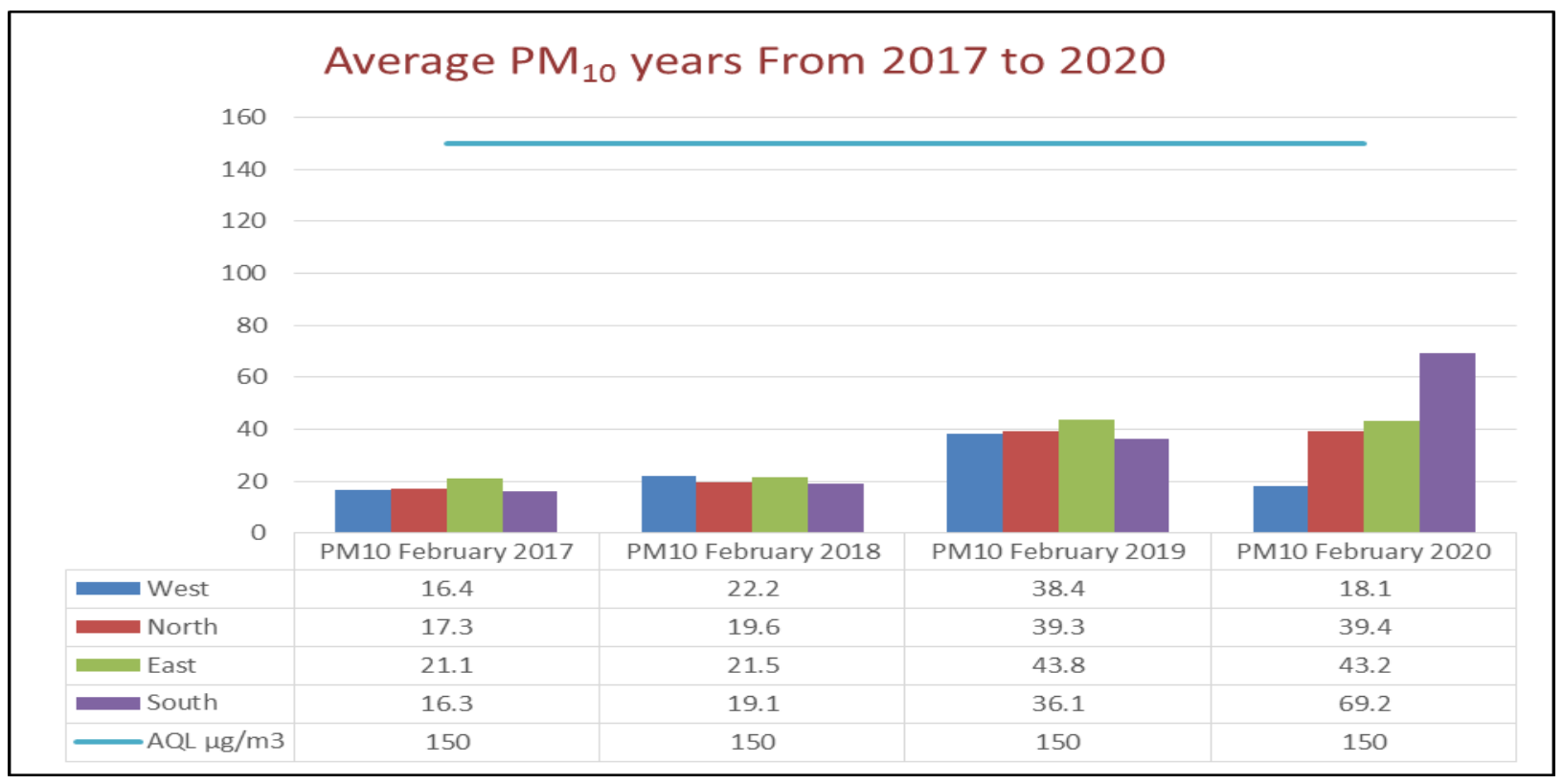

Figure 6.thoracic particle concentrations (micrograms per cubic meter).

Source: Author own calculations.

Noise was measured in the four geographical directions at Sokhna Port as shown in Table No. (4) and in Figure (7).

Table 4. Average noise levels (in decibels) in El Sokhna port

Site No.

Air Quality Limit

$\mathrm{AQL}=70 \mathrm{db}$ 
International Journal of Agriculture, Environment and Bioresearch

Vol. 5, No. 06; 2020

ISSN: $2456-8643$

\begin{tabular}{|r|r|l|l|l|}
\hline & $\begin{array}{r}\text { Average Noise } \\
\mathbf{2 0 1 7}\end{array}$ & $\begin{array}{r}\text { Average Noise } \\
\mathbf{2 0 1 8}\end{array}$ & $\begin{array}{r}\text { Average Noise } \\
\mathbf{2 0 1 9}\end{array}$ & $\begin{array}{r}\text { Average Noise } \\
\mathbf{2 0 2 0}\end{array}$ \\
\hline West & 16.4 & 22.2 & 38.4 & 18.1 \\
\hline North & 17.3 & 19.6 & 39.3 & 39.4 \\
\hline East & 21.1 & 21.5 & 43.8 & 43.2 \\
\hline South & 16.3 & 19.1 & 36.1 & 69.2 \\
\hline
\end{tabular}

Source: Author own calculations.

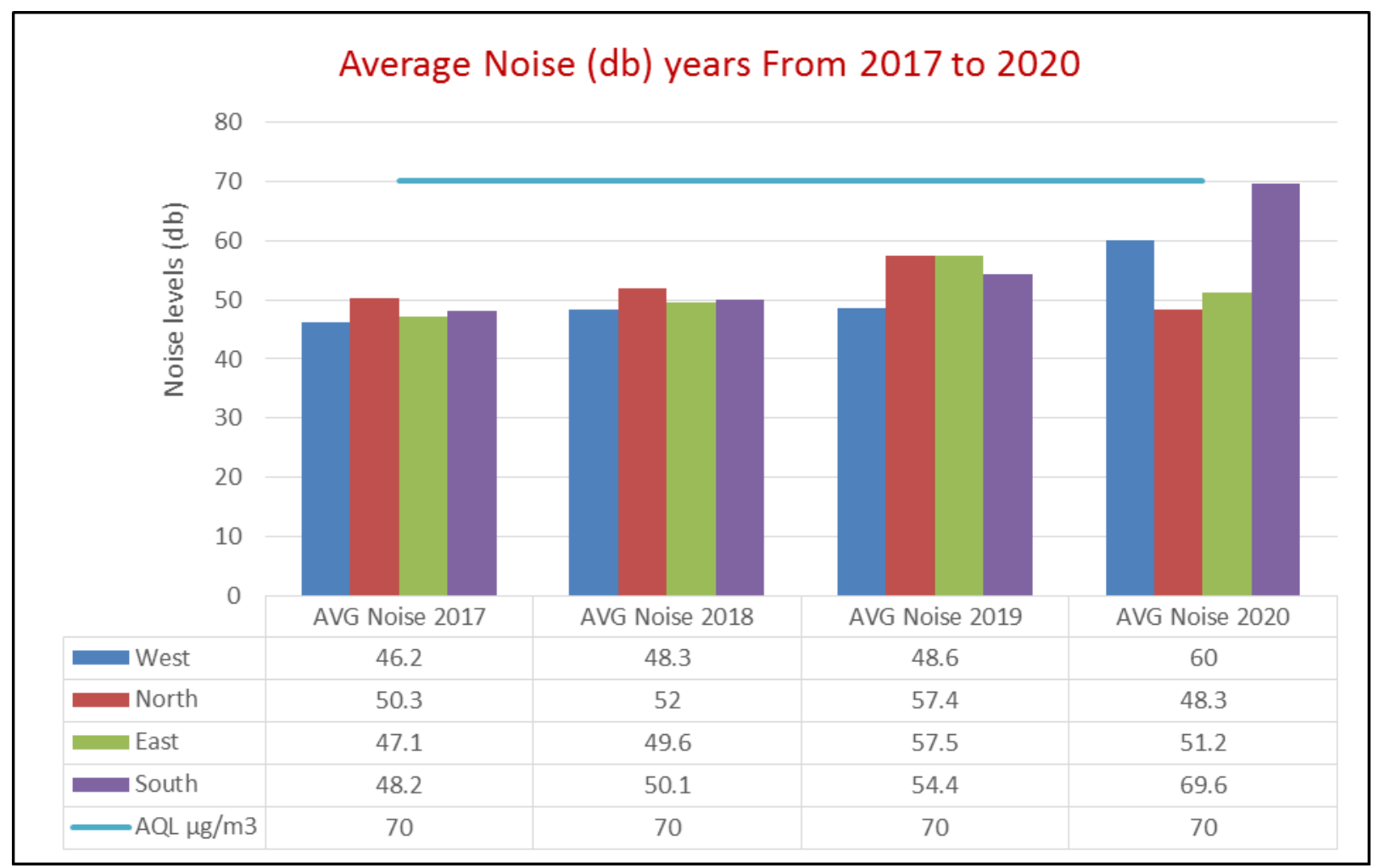

Figure 7. average noise levels (dB) over the years 2017 to 2020.

Source: Author own calculations.

The total volatile organic gases were measured in the four geographical directions at El Sokhna Port, as shown in Table No. (5) and Figure No. (8). 
International Journal of Agriculture, Environment and Bioresearch

Vol. 5, No. 06; 2020

ISSN: $2456-8643$

Table .5 Average Volatile Total Organic Gas Concentrations (ppm) in Sokhna Port

\begin{tabular}{|r|l|l|r|r|}
\hline \multirow{2}{*}{ Site No. } & \multicolumn{5}{|l|}{ No AQL } & \multicolumn{5}{|l|}{ Air Quality Limit } \\
\cline { 2 - 6 } & $\begin{array}{r}\text { Average TVOC } \\
\mathbf{2 0 1 7}\end{array}$ & $\begin{array}{r}\text { Average TVOC } \\
\mathbf{2 0 1 8}\end{array}$ & $\begin{array}{r}\text { Average TVOC } \\
\mathbf{2 0 1 9}\end{array}$ & $\begin{array}{r}\text { Average TVOC } \\
\mathbf{2 0 2 0}\end{array}$ \\
\hline West & 0.001 & 0.002 & 0.131 & 0.009 \\
\hline North & 0.002 & 0.003 & 0.123 & 0.012 \\
\hline East & 0.002 & 0.002 & 0.263 & 0.012 \\
\hline South & 0.001 & 0.003 & 0.140 & 0.024 \\
\hline
\end{tabular}

Source: Author own calculations.

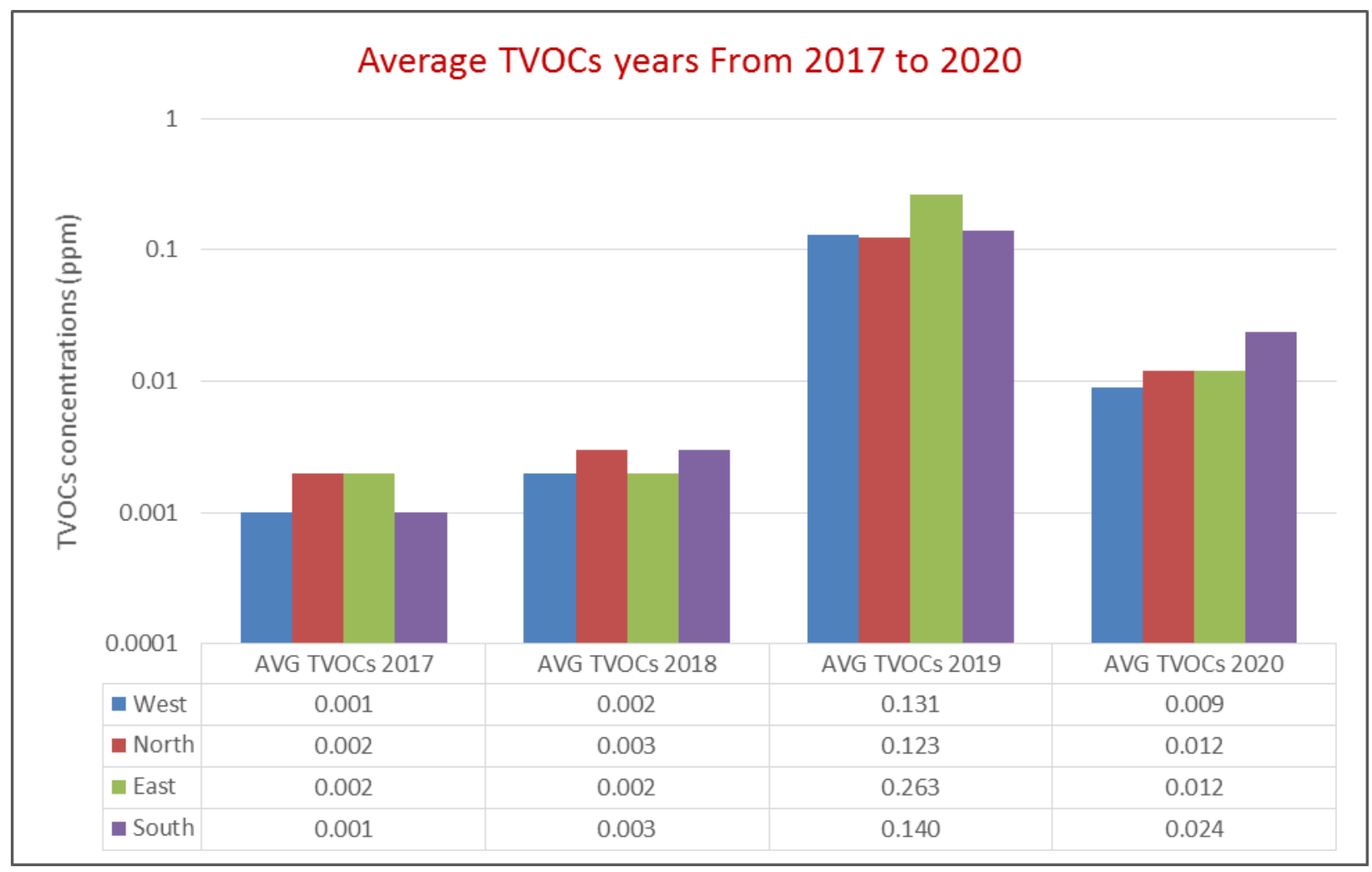

Figure 8. average concentrations of total volatile organic gases (parts per million).

Source: Author own calculations. 


\section{Weather of Alexandria Port:}

Alexandria has a mild climate characterized by hot and dry summers and wet, mild and rainy winters. The winter in Alexandria extends through the months of December, January and February and the temperature is between 12 and 18 degrees Celsius during this season. Alexandria is subject to many severe thunderstorms, hail, heavy rain and the average annual rainfall in the summer in Alexandria extends through the months of June, July and August with a temperature between 25 and 39 degrees Celsius.

Alexandria's summer is characterized by drought and high humidity, while spring and autumn are the best time to visit the city, and the maximum temperature is about $25^{\circ} \mathrm{C}$, except for the time of the sirocco "dusty winds", when the temperature in the spring months sometimes reaches $34^{\circ} \mathrm{C}$. There are some severe sandstorms coming from some deserts. Figures $(4: 1)$ show wind trend data for conditions of air in all the classes in the area covered in this study, which was taken from the nearest monitoring stations (Burj Al Arab monitoring station) during the year 2017 until the beginning of 2020.

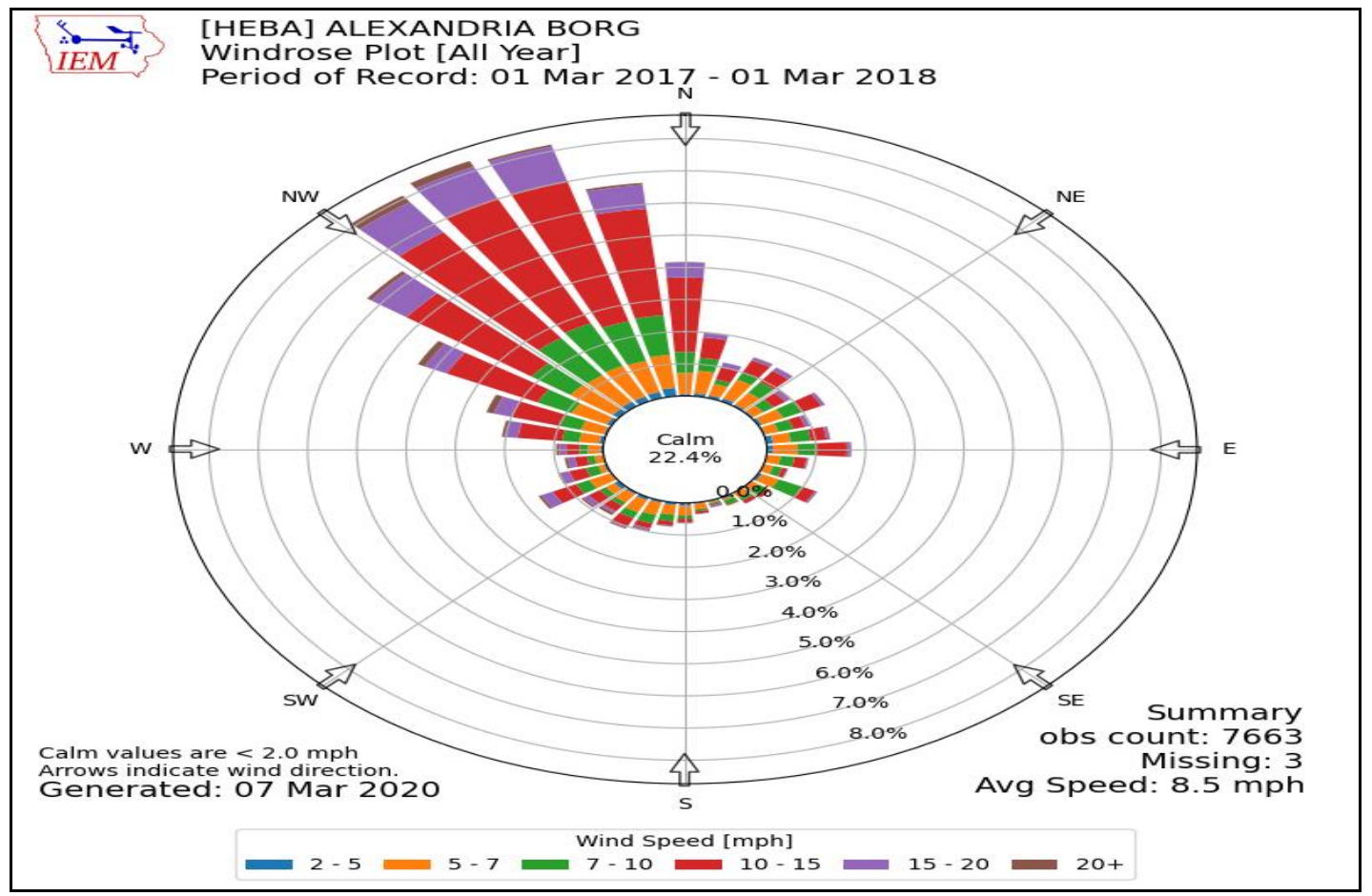

Figure 1. Shows the prevailing wind direction during 2017-2018.

Source: Author own calculations. 
Vol. 5, No. 06; 2020

ISSN: $2456-8643$

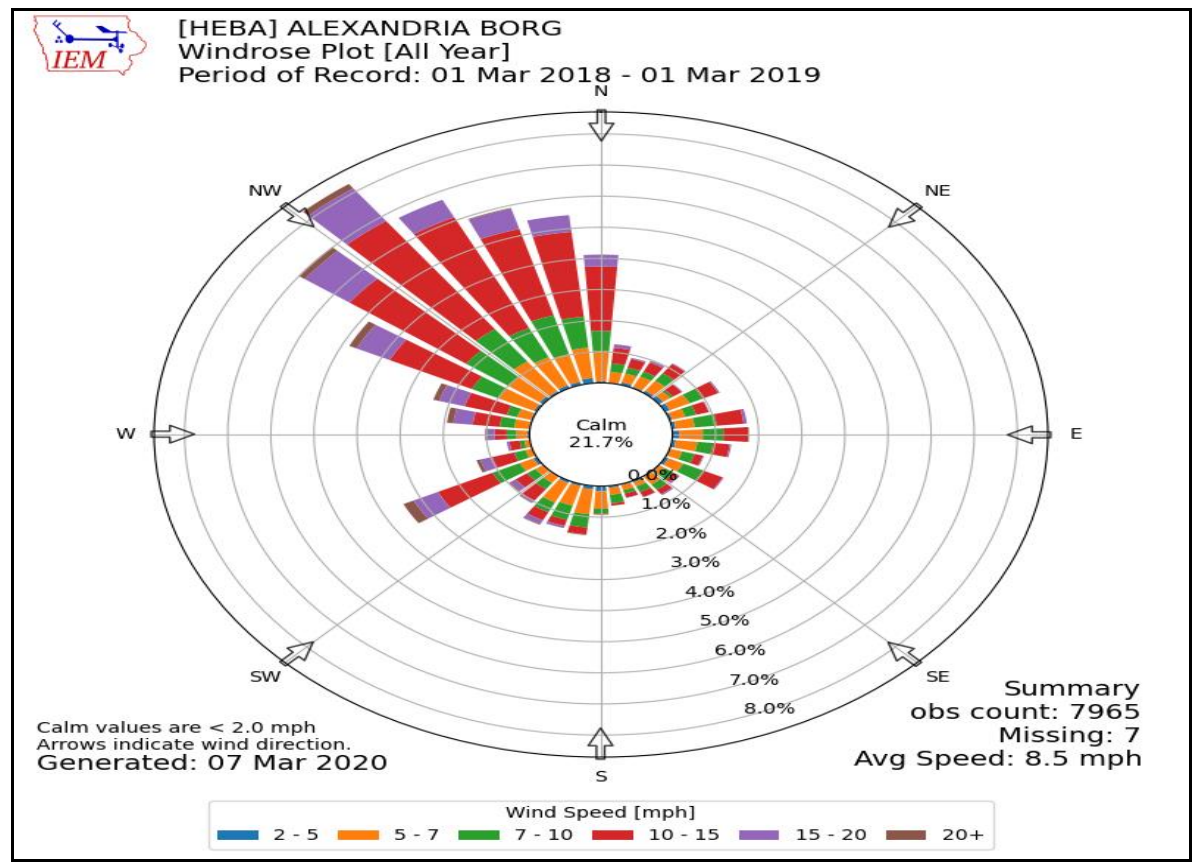

Figure 2. shows the prevailing wind direction during the year 2018-2019.

Source: Author own calculations.

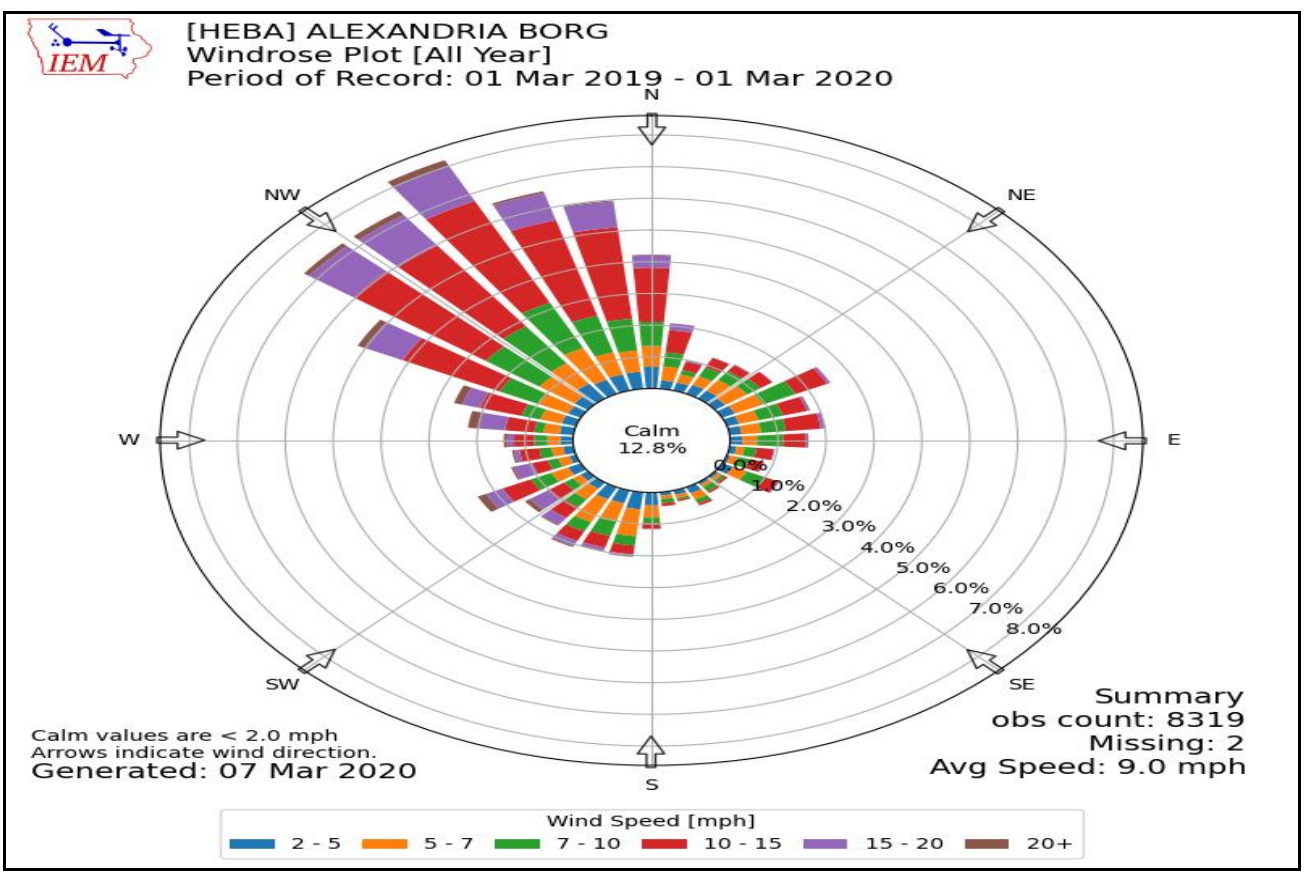

Figure 3. shows the prevailing wind direction during the year 2019-2020. 
Source: Author own calculations.

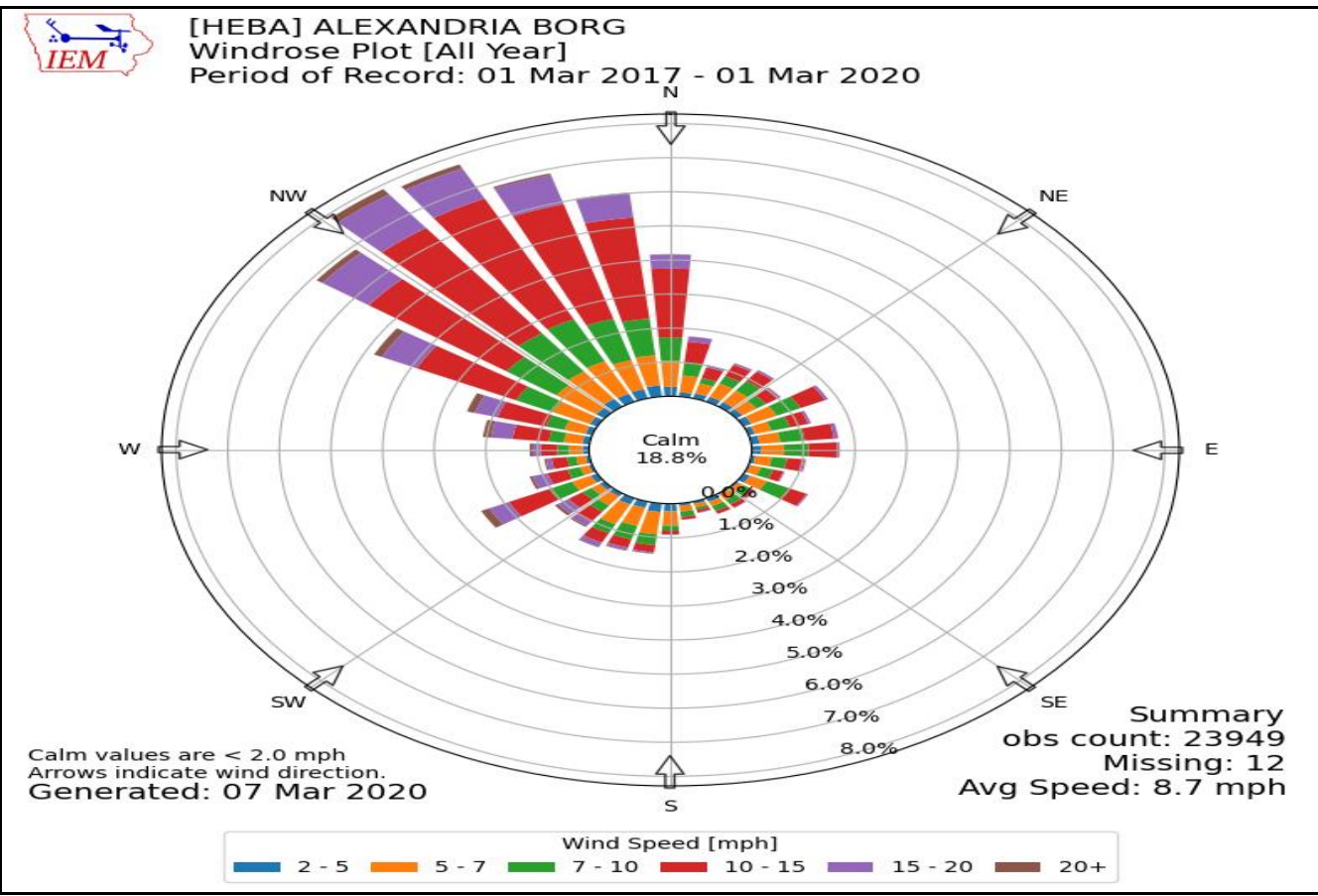

Figure 4. wind trends prevailing in Alexandria from March 2017 to March 2020.

Source: Author own calculations.

The has visited the site, measured the coordinates, selected a number of spots to monitor the various air pollutants around the port, especially the areas above the wind and under the wind, to determine the air quality in the region using many equipments as in table (1), which shows the pollutants and the methods of measuring them scientifically.

Table 1. the different methods and devices used to monitor air quality in the study area

\begin{tabular}{|c|c|c|}
\hline Pollutants / Elements & The technique used & The used device \\
\hline $\begin{array}{l}\text { TSP } \\
\text { (The suspended overall } \\
\text { dust) }\end{array}$ & \begin{tabular}{|r} 
dust collection (Filtration and \\
Deposition)
\end{tabular} & Volume sampler \\
\hline $\begin{array}{l}\text { PM10 } \\
\text { (Thoracic particles) }\end{array}$ & \begin{tabular}{|lr} 
dust collection & (Filtration and \\
& \\
Deposition)
\end{tabular} & Air Matrix \\
\hline Noise & Sound Levels' Sensor & Noise meter \\
\hline $\begin{array}{l}\text { VOC } \\
\text { (Volatile organic gases) }\end{array}$ & $\begin{array}{r}\text { Photo Ionization Detector PID } \\
\text { Gas Chromtograph (GC) }\end{array}$ & $\begin{array}{r}\text { VOC monitor } \\
\text { and sampling canister }\end{array}$ \\
\hline
\end{tabular}


Vol. 5, No. 06; 2020

ISSN: $2456-8643$

\begin{tabular}{|r|r|r|}
\hline Photos & -- & $\begin{array}{r}\text { igital Camera and Satellite } \\
\text { image }\end{array}$ \\
\hline Geographical locations & & GPS \\
\hline
\end{tabular}

Source: Author own calculations.

Total suspended particulates and thoracic particulates have been measured by several locations around and inside the port. The north-west winds are moving in the direction of the south and south-east and the nature of the place is coastal and the nature of Egypt's environment is desert sandy /rock, therefore, one of the sources of total suspended particulates is from a natural source. The measurements of the outstanding total dust were done as shown in table (2) and figure (5) and it was found out that all the points measured were not only matching the limits allowed under the Egyptian Environment Act in accordance, but also with the latest amendments to the law number 9 of the year 2009 .

Table 2. Average of the total suspended dust concentrations (micrograms per cubic meter) around the Alexandria port site

\begin{tabular}{|r|r|r|r|r|}
\hline \multirow{2}{*}{ Site No. } & \multicolumn{5}{|r|}{$\begin{array}{r}\text { Air Quality Limit } \\
\text { AQL }=230 \mu \mathrm{\mu g} / \mathrm{m}^{3}\end{array}$} \\
\cline { 2 - 6 } & $\begin{array}{r}\text { Average TSP } \\
\mathbf{2 0 1 7}\end{array}$ & $\begin{array}{r}\text { Average TSP } \\
\mathbf{2 0 1 8}\end{array}$ & $\begin{array}{r}\text { Average TSP } \\
\mathbf{2 0 1 9}\end{array}$ \\
\hline West & 31 & 37 & 32 & 39 \\
\hline North & 36 & 42 & 52 & 42 \\
\hline East & 44 & 43 & 63 & 61 \\
\hline South & 49 & 51 & 71 & 74 \\
\hline
\end{tabular}

Source: Author own calculations. 


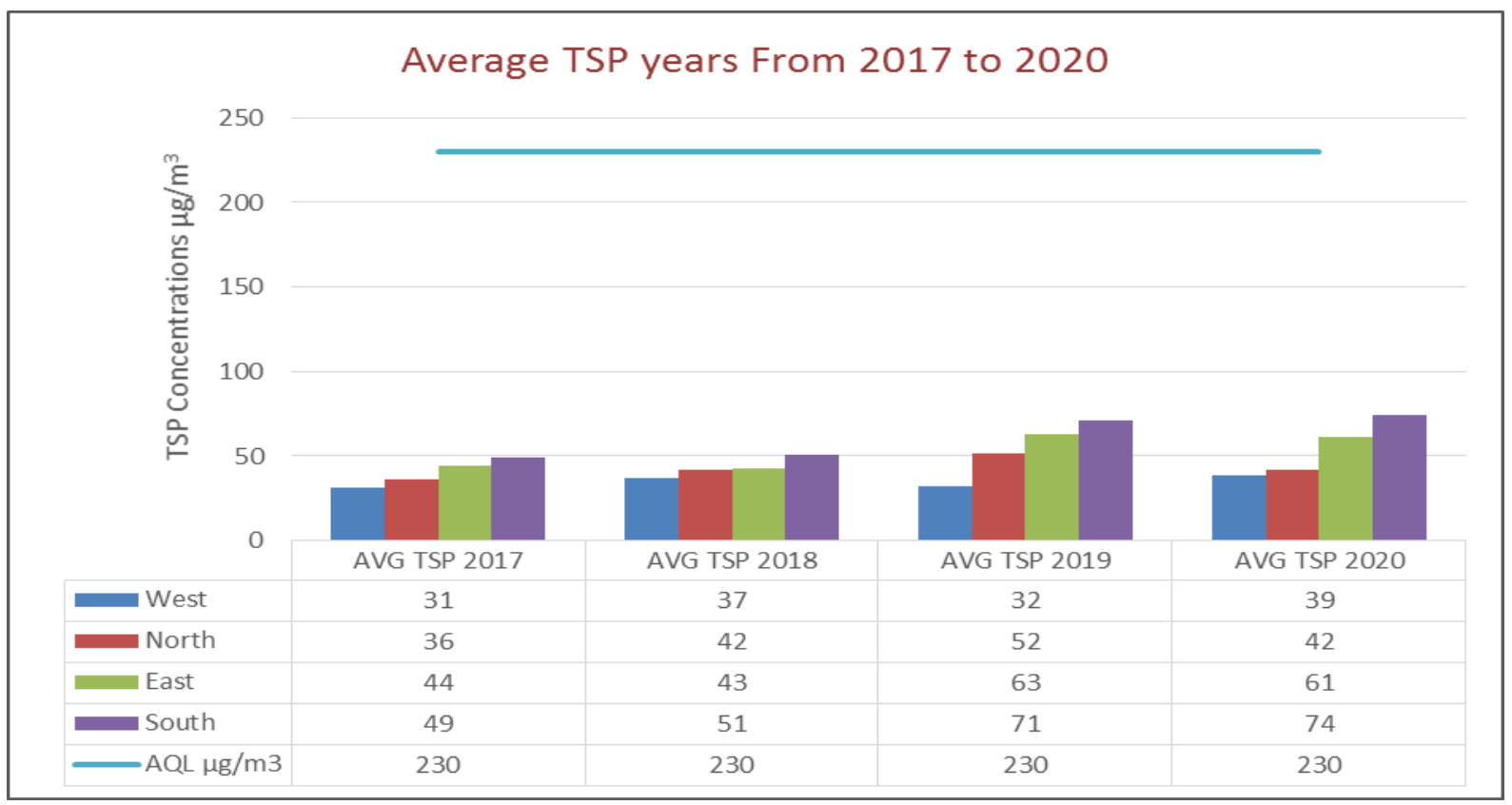

Figure 5. the average of the total suspended dust concentrations (micrograms per cubic meter).

Source: Author own calculations.

The thoracic concentrations is less than 10 micrometers in all locations, which is shown in table number 3 and in figure (6). Natural or artificial factors can play a major role in increasing suspended particulates and thoracic particulates.

Table 3. Average thoracic particle concentrations (micrograms per cubic meter) around the Alexand ria port site

\begin{tabular}{|c|c|c|c|c|}
\hline \multirow{2}{*}{ Site No. } & \multicolumn{4}{|c|}{$\begin{array}{l}\text { Air Quality Limit } \\
\mathrm{AQL}=150 \mu \mathrm{g} / \mathrm{m}^{3}\end{array}$} \\
\hline & $\begin{array}{r}\text { Average } \text { PM }_{10} \\
2017\end{array}$ & $\begin{array}{r}\text { Average } \mathbf{P M}_{10} \\
2018\end{array}$ & $\begin{array}{r}\text { Average } \mathbf{P M}_{10} \\
2019\end{array}$ & $\begin{array}{r}\text { Average } \mathbf{P M}_{10} \\
2020\end{array}$ \\
\hline West & 11 & 16 & 13 & 31 \\
\hline North & 14 & 17 & 15 & 17 \\
\hline East & 17 & 18 & 19 & 18 \\
\hline South & 19 & 20 & 22 & 25 \\
\hline
\end{tabular}

Source: Author own calculations. 


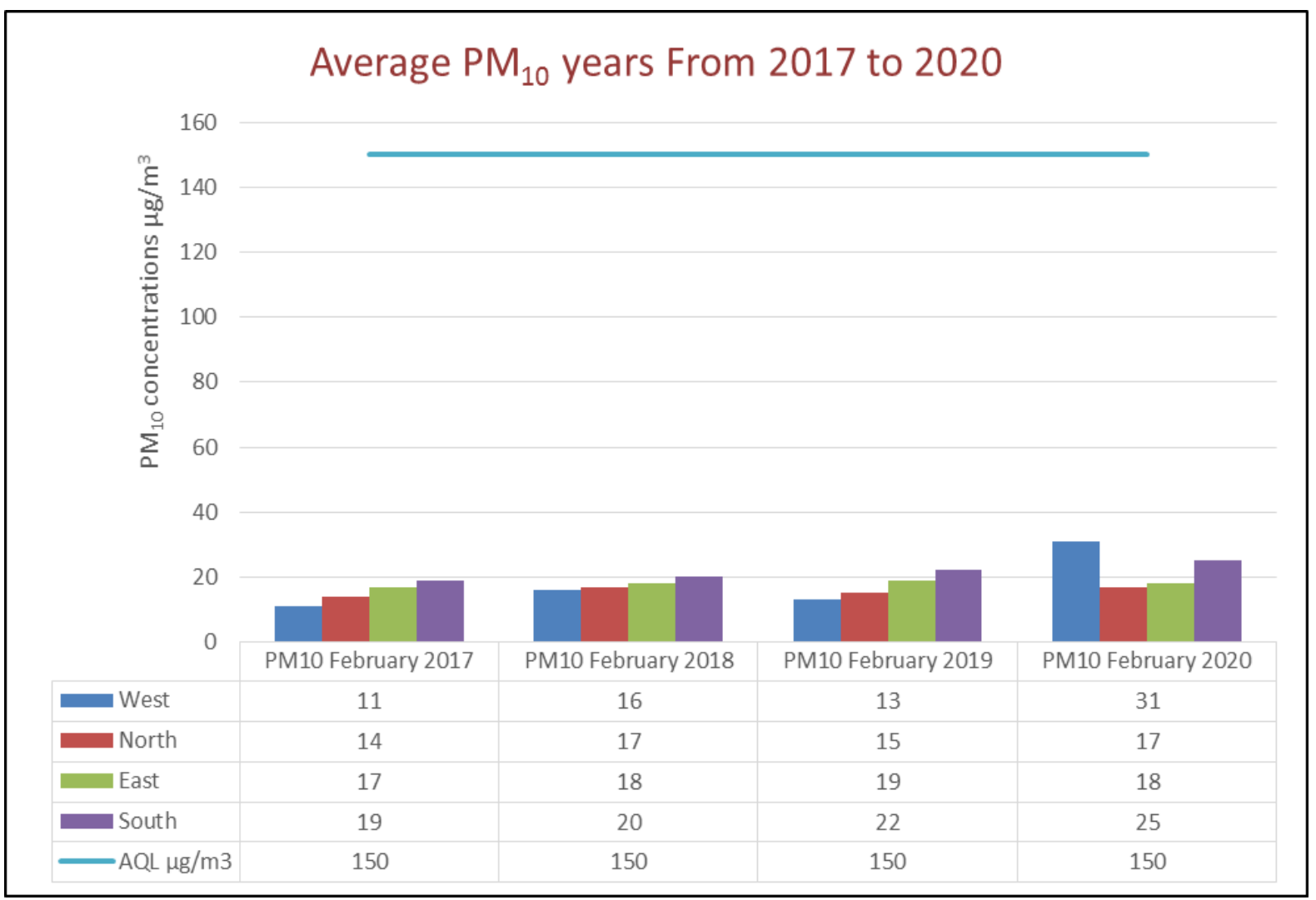

Figure 6 .thoracic particle concentrations (micrograms per cubic meter).

Source: Author own calculations.

Noise was measured in the four geographical directions at Alexandria port, as shown in Table No. (4) and in Figure (7).

Table 4. Average noise levels (in decibels) in Alexandria port

\begin{tabular}{|r|r|r|r|r|}
\hline \multirow{2}{*}{ Site No. } & \multicolumn{5}{|c|}{$\begin{array}{r}\text { Air Quality Limit } \\
\text { AQL=70 db }\end{array}$} \\
\cline { 2 - 6 } & $\begin{array}{r}\text { Average Noise } \\
\mathbf{2 0 1 7}\end{array}$ & $\begin{array}{r}\text { Average Noise } \\
\mathbf{2 0 1 8}\end{array}$ & $\begin{array}{r}\text { Average Noise } \\
\mathbf{2 0 1 9}\end{array}$ & $\begin{array}{r}\text { Average Noise } \\
\mathbf{2 0 2 0}\end{array}$ \\
\hline West & 61.6 & 62.6 & 66.1 & 65.1 \\
\hline North & 62.7 & 61.7 & 67.4 & 66.4 \\
\hline East & 64.1 & 65.1 & 61.3 & 63.3 \\
\hline
\end{tabular}


International Journal of Agriculture, Environment and Bioresearch

Vol. 5, No. 06; 2020

ISSN: $2456-8643$

\begin{tabular}{|r|l|l|l|l|}
\hline South & 63.4 & 63.7 & 64.8 & 61.8 \\
\hline
\end{tabular}

Source: Author own calculations.

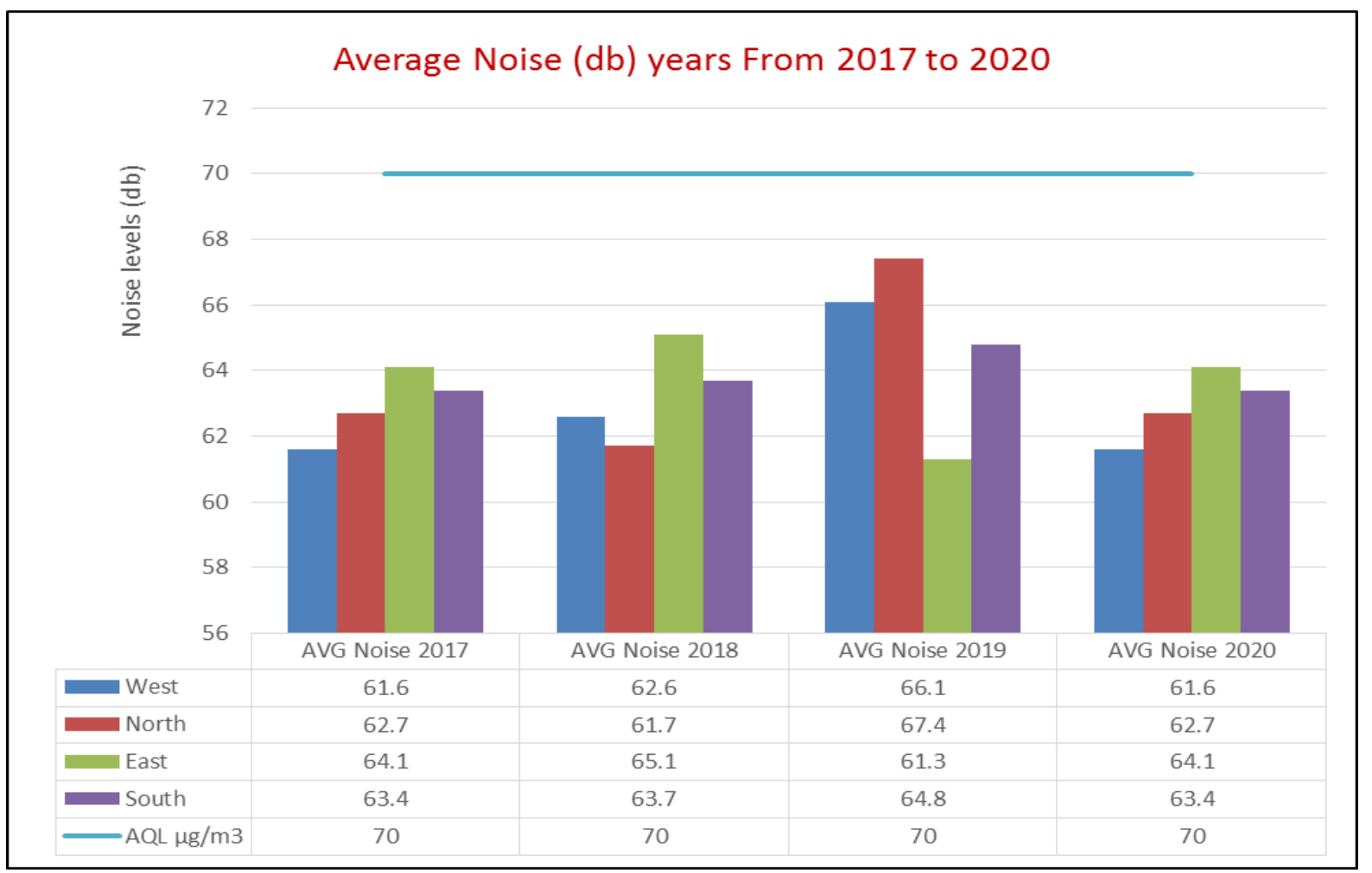

Figure 7. Average noise levels (dB) over the years 2017 to 2020.

Source: Author own calculations.

The total volatile organic gases were measured in the four geographical directions at Alexandria port, as shown in the following table No. (5) and in the following figure No. (8).

Table 5. Average concentrations of Total Volatile Organic Gases (ppm) in Alexandria Port

\begin{tabular}{|r|r|r|r|r|}
\hline \multirow{2}{*}{ Site No. } & \multicolumn{2}{|l}{ No AQL } \\
\cline { 2 - 6 } & Average TVOC & Average TVOC & Average TVOC & Average TVOC \\
& $\mathbf{2 0 1 7}$ & $\mathbf{2 0 1 8}$ & $\mathbf{2 0 1 9}$ & $\mathbf{2 0 2 0}$ \\
\hline West & 4.9 & 3.2 & 2.9 & 1.7 \\
\hline
\end{tabular}


International Journal of Agriculture, Environment and Bioresearch

Vol. 5, No. 06; 2020

ISSN: $2456-8643$

\begin{tabular}{|r|l|l|l|l|}
\hline North & 4.6 & 3.3 & 2.8 & 1.5 \\
\hline East & 4.2 & 3.6 & 2.5 & 1.2 \\
\hline South & 3.8 & 3.8 & 2.1 & 0.9 \\
\hline
\end{tabular}

Source: Author own calculations.

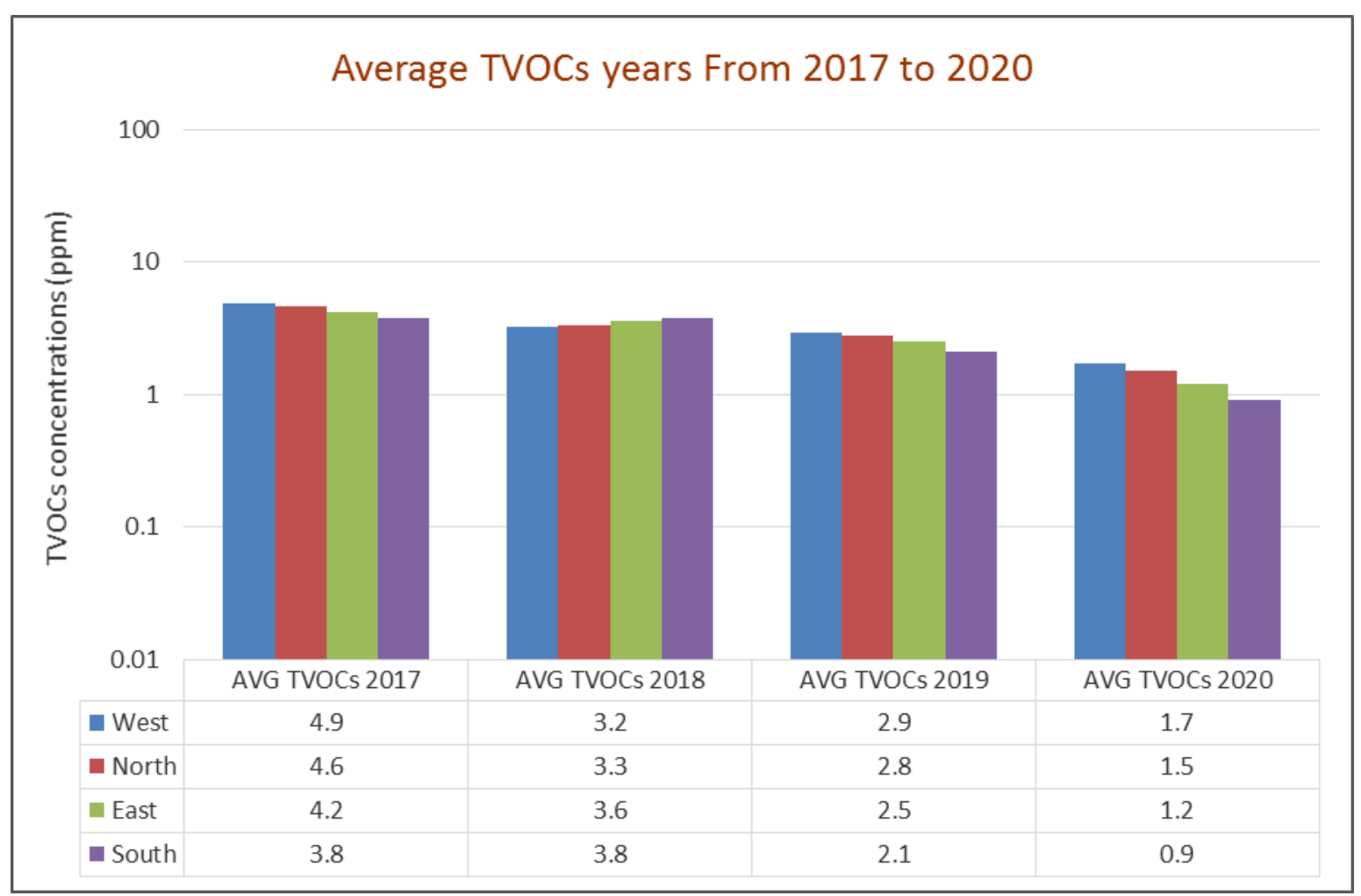

Figure 8. average concentrations of total volatile organic gases (parts per million).

Source: Author own calculations.

\section{RESULTS AND RECOMMENDATIONS}

The table in Appendix 1 shows a discrepancy between the responses of the study sample from the port of Alexandria and Sokhna:

- The response rate of employees related to the availability of the environmental impact assessment is (22.5\%) Yes (77.5\%) No in the port of Alexandria, and (82.8\%) Yes and (16.3\%) No in the port of Sokhna.

- The response rate of employees related to the occurrence of planning is (15.0\%) Yes and (85.0\%) No in the port of Alexandria, and (80\%) Yes and (20\%) No in the port of Sokhna. 
- The response rate of employees related to the execution and operation is $(27.5 \%)$ Yes and $(72.5 \%)$ No at the Port of Alexandria, while the ratio in Sokhna Port is $(83.8 \%)$ Yes and (16.2\%) No.

- The response rate of employees related to the presence of screening and correction (control) within the port is $(17.5 \%)$ Yes and $(82.5 \%)$ No in the port of Alexandria, and $(88.88 \%)$ Yes and $(11.2 \%)$ No in the port of Sokhna.

- The response rate of employees related to the presence of the administrative review and management audit within the port is $(12.5 \%)$ Yes and $(87.5 \%)$ No in the port of Alexandria, and $(91.3 \%)$ Yes and $(8.7 \%)$ No in the port of Sokhna.

According to the findings, it is clear that the port of Alexandria does not match the requirements of the Environmental Impact Assessment management in terms of the overall quality, while the Port of Sokhna has the requirements of the Environmental Impact Assessment. For the mentioned reason, the researcher has searched for the reasons of the lack of requirements at the port of Alexandria and came up with a proposal to provide the requirements of the Environmental Impact Assessment system at the port of Alexandria. Finally, the researcher recommended that further studies should be conducted on analyzing water using more advanced tools.

\section{REFERENCE}

1. Chendvong, S. A. (2011) “A current Environmental Impact Assessment of a port in Thailand: Marine physical aspects Ocean \& Coastal Management”, 54 (2). pp.101-109.

2. Chikuku, T.; Musaidzi, H.; \& Nyoni, N. (2011). The Role of Green Manufacturing/Cleaner Production in Obtaining ISO 14001 Certification for Tobbacoo Processing Companies in Zimbabwe. ISEM .

3. Damanki, M. (2010) "Integrating Maritime Surveillance". Available at: www.ec.europa.eu/maritimeaffairs/policy/integrated_maritime_surveillance/documents/in tegrating_maritime_surveillance_en.pdf. Accessed date: 04th Feb.2016 at: 04:27 pm.

4. European Commission (2010) "Towards an Integrated Maritime Policy for better Governance in the Available at: www.vliz.be/imisdocs/publications/222376 pdf Accessed date 07th Oct 2016 at: 11:03

5. Hansen, P.I.; Christiansen, K.; \& Hummelmose, B. (2000). Cleaner Production Assessment in Meat Processing. UNEP DTIE, DEPA, Denmark .

6. Jon, B. (2009) "EU Strategy to Improve Maritime Governance in the Mediterranean Sea". Available

www.eeas.europa.eu/delegations/albania/documents/news/2009/20090912_en.pdf.

Accessed date: 06th Feb.2016 at: 08:22 am.

7. Katherine Daughtry, Environmental Management Systems: A Review of Available Standards and a Survey on Implementation in Swedish Organisations, 2015.

8. Lappalainen, J. Storgård, J and Ulla.T. (2013("The Effectiveness of maritime Safety Policy Instruments from the Finnish Maritime Experts Point of View - Case Gulf of Finland and Prevention of an Oil Accident". University of Turku, Centre for Maritime Studies Maritime University, Finland. Available at: 
www.link.springer.com/content/pdf/10.1007/2fbf03195165.pdf. Acceded date: 16th jan.2017 at: 09:00 am.

9. Ming, X. (2000) "China Maritime Safety Administration in the New Millennium: Challenges and Strategies". MSc thesis, Malmo Sweden, World Maritime University. Available at: www.commons.wmu.se/all_dissertations. Accessed date: 17thOct.2016 at: 09:13 pm.

10. Neuman, W. L. (2014) "Social Research Methods: Qualitative and Quantitative Approaches", 7th ed. Pearson.

11. Rasha El Gohary\& Tamer El Gohary (June 2017) "Environmental Impact Assessment (EIA) Guidelines for Development of Ports Harbours and Marines along Egyptian Mediterranean Coast-A Case Study". International Journal of Current Engineering and Technology, National water research center .

12. Saunders, M., Lewis, P. and Thornhill, A. (2009) "Research Methods for Business Students", 5th ed. London: Pearson Education, Limited.

13. Viertola, J. (2013) "Maritime Safety in the Gulf Of Finland, Evaluation of the regulatory system" University of Turku, Centre for Maritime Studies Maritime University, Finland. Available at: www.doria.fi/bitstream/handle/10024/94150/A67- maritime safety in the Gulf of Finland. pdf. Accessed date: 17th Sept.2016 at: 11:04 pm

14. Viertola, J. and Storgård, J. (2013)"Overview on the Cost Effectiveness of Maritime Safety Policy Instruments" .University of Turku, Centre for Maritime Studies Maritime University, Finland. Available at: www.merikotka.fi/mimic/images/stories/Viertola_Over view on the CostEffectiveness.pdf. Accessed date: 27th Apr 2016 at: 12:56 